\title{
Multiple Reticulohistiocytomas in an 88-year-old Man: a Case Report
}

\author{
Branislava GAJIĆ ${ }^{1 *}$, Tatjana ROŠ ${ }^{1}$, Andrijana ARAPOVIĆ ${ }^{1}$, \\ Nada VUČKOVIĆ ${ }^{2,3}$, Aleksandra FEJSA LEVAKOV ${ }^{2,3}$ \\ 1 Clinic of Dermatovenereology Diseases, Clinical Center of Vojvodina, Novi Sad, Serbia \\ 2 Center for Pathology and Histology, Clinical Center of Vojvodina, Novi Sad, Serbia \\ 3 Faculty of Medicine, University of Novi Sad, Serbia \\ ${ }^{*}$ Correspondence: Branislava Gajić, E-mail: brana.gajic@yahoo.com
}

UDC 616.5-006.44-07/-08

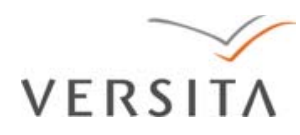

\begin{abstract}
Solitary and multiple reticulohistiocytomas, often referred to as diffuse cutaneous reticulohistiocytosis, that are generally restricted to skin, must be differentiated from multicentric reticulohistiocytosis. Multicentric reticulohistiocytosis is a rare histiocytic proliferative disease affecting joints, skin and mucous membranes, while arthropathy usually precedes skin and mucosal involvement. Other organs may also be involved, and $20 \%$ of patients have an associated internal malignancy. Multicentric reticulohistiocytosis has been reported to be associated with autoimmune diseases and malignancies.

We present an 88-year-old man, with a sudden eruption of asymptomatic, firm, skin to brown colored papules and nodules, 6 to $17 \mathrm{~mm}$ in diameter, localized on forehead, arms, legs, and buttocks. There were no symptoms of joint or other organ involvement. Clinical and dermoscopic characteristics pointed to reticulohystiocytomas. Multiple excision biopsies of different tumors were performed and histopathology reports confirmed the diagnosis. In the case presented, reticulohistiocytosis was limited to the skin, exhibiting multiple reticlohistiocytomas with typical clinical, dermoscopic and rather peculiar histopathology presentation. Apart from this, some histologic features were seen in early lesions of multicentric reticulohistiocytosis, such as multinuclear cells dissociating collagen fibers with pale eosinophilic and foamy cytoplasm. Besides surgical excisions, no other treatment options were done. Laboratory and other tests showed no presence of extracutaneous illness, and no autoimmune or paraneoplastic processes. At one year follow up, the remaining tumors were of the same size, but there were no recurrences at excision sites, no signs of disease progression or systemic involvement. Since diffuse cutaneous reticulohistiocytosis without arthropathy as well as isolated reticulohistiocytomas have been described, in some cases of multiple reticulohistiocytomas even without systemic symptoms and signs, multicentric reticulohistiocytosis should be considered with an appropriate follow up. In such cases, skin lesions have the same histological features as lesions in multicentric reticulohistiocytosis, but they are not associated with joint problems or neoplasms.
\end{abstract}

\section{Key words}

Histiocytosis, Non-Langerhans-Cell; Dermoscopy; Histology; Signs and Symptoms; Aged, 80 and over

$\mathrm{T}$ he histiocytoses are a group of proliferative disorders that have a common progenitor cell in the bone marow. In general, these disorder are broadly devided into Langerhans cell and non-Langerhans cell histiocytosis $(1,2)$. Reticulohistiocytoma is a non-Langerhans cell histiocytosis also involving cells other than dermal dendrocytes, which is a rare, generally solitary and asymptomatic skin tumor of unknown etiology. Solitary and multiple reticulohistiocytomas RHs, often referred to as diffuse cutaneous reticulohistiocytosis are: generally restricted to skin neither associated with arthropathy nor internal malignancy; must be differentiated from multicentric reticulohistiocytosis (MRH). Multicentric reticulohistiocytosis is a rare histiocytic proliferative disease affecting joints, skin and mucous 
membranes, while arthropathy usually precedes skin and mucosal involvement. Other organs may also be involved, and $20 \%$ of patients have an associated internal malignancy. MRH has been reported to be associated with autoimmune diseases and fatal cardiac involvement, and widespread systemic involvement (3). Constitutional symptoms commonly include fever, malaise, weakness and weight loss.

Multiple cutaneous RHs rarely present without any evidence of systemic disease $(1,2)$, and it has been suggested that in such cases extracutaneous features may develop at any time (4). We present an 88 yearold patient who developed multiple cutaneous RHs and remained systemic disease-free after a year followup.

\section{Case report}

An 88-year-old man, a retired lawyer, who was referred to our Clinic with earlyer medical history of benign prostatic hyperplasia and cerebrovascular insult, presented with a sudden onset of widespread asymptomatic cutaneous eruption of papules and nodules, gradually progressing within the following 3 months. There were no mucosal lesions, no history of joint diseases, or constitutional symptoms. Complete skin examination revealed firm, round, wellcircumscribed, skin to brown colored papules and nodules, $6-17 \mathrm{~mm}$ in diameter, affecting the patient's forehead, arms, legs and buttocks (Figures 1 and 2). The rest of the systemic examination was normal.

Dermoscopy of forehead lesions revealed a homogeneous yellow pattern with central white scar-like streaks (Figure 3a); the same appearance was seen on the right and left upper arms, with an erythematous, slightly brownish halo and some vessels on the periphery (Fiugres 3b, c); a central homogeneous yellow pattern with whitish scar-like streaks and a bright to dark livid halo with brown linear and reticular structures at the periphery were seen on the four different lesions on the lower limbs (Figures $4 \mathrm{a}-\mathrm{d}$ ).

Multiple excision biopsies from the forehead, both arms, and buttocks were performed and histopathological examination revealed and confirmed RHs.

Histopathology of four exhcised nodules exibited similar characteristics: the epidermis was centrally slightly distended over the lesion, but preserved over the dermal infiltrate (Figure 5a); diffuse infiltrates of histiocytes involved the whole dermis showing areas of storiform pattern (Figure 5b); the infiltrates consisted of some lymphocytes and eosinophilic granulocytes as well as broad thick collagen bundles (Figure 5c); histiocytes were mostly mononuclear, but a few were

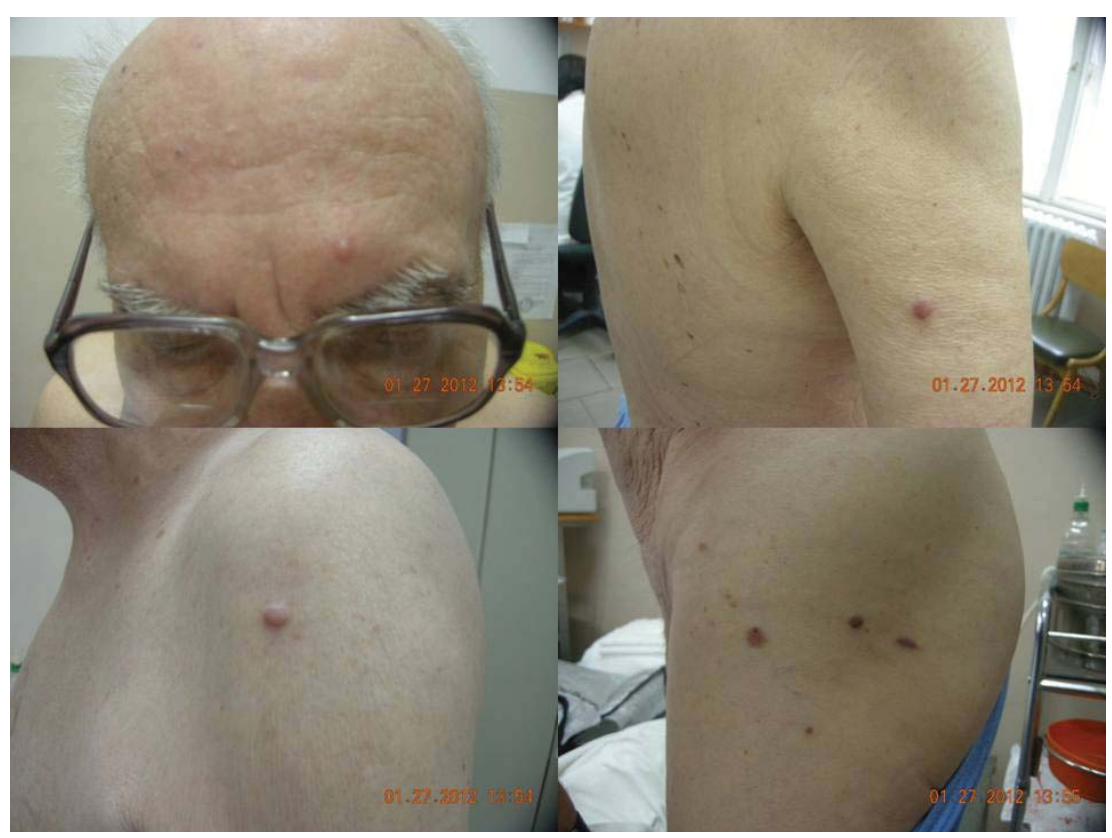

Figure 1. Skin colored to brownish nodules located on the forehead, right and left arm and the buttocks 


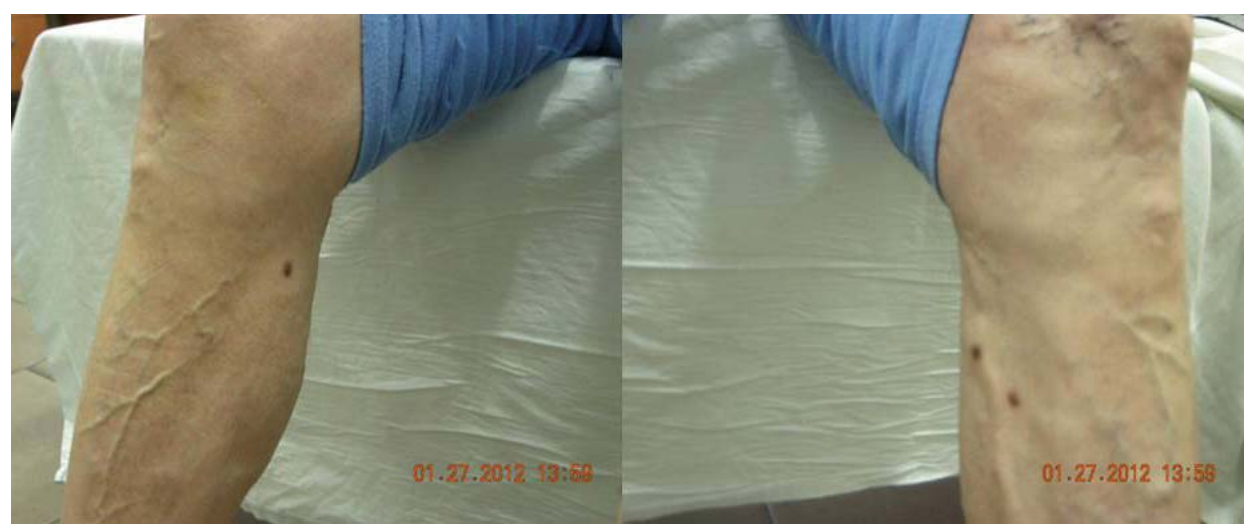

Figure 2. Brownish nodules on the lower legs

multinuclear, the cytoplasm was pale, eosinophilic and foamy; the staining with CD34 and S-100 was negative, but with CD68 - it was diffusely positive (Figure 5d).

Laboratory tests were within normal values including: erythrocyte sedimentation rate, complete blood count with differential, urinanalysis, lipid status, renal and liver biochemistry, serum levels of amylase, lipase, lactate dehydrogenase, alanine aminotransferase, aspartate aminotransferase, gamma glutamyl transpeptidase, tumor markers such as carcinoembryonic antigens (CEA), alpha fetoprotein antigens (AFP), carbohydrate antigen (CA 19-9) and prostate serum antigens (PSA), as well as immunology parameters such as rheumatoid factor, antinuclear antibodies, cold agglutinins and cryoglobulins.

Chest X-ray and abdominal ultrasound showed no signs of MRH or malignancies. Plain $\mathrm{x}$-ray showed marked osteoporosis of the hands and feet and mild narrowing of proximal interphalangeal space of the fifth finger of the right hand.

Annual follow up showed that RHs persisted in number and size, but there was no systemic disease and no new RHs developed.

\section{Discussion}

Solitary RHs are confined to the skin, but when multiple tumors develop they usually represent an introduction into a rare systemic disease $-\mathrm{MRH}$. The etiopathogenesis of MRH remains unknown. It has been suggested that a yet unidentified stimulus may trigger proliferation of reactive histiocytes (1), and that destructive, mainly osteolytic lesions are due to the action of protease released by infiltrating cells as well as proinflammatory cytokines, TNF- $\alpha$ and IL-1, in inducing osteoclastic activity $(3,5)$.

Multiple reticulohistiocytosis predominantly affects Caucasians, and three times more frequently women than men. The mean age of onset is in the fourth decade of life, although it may also affect children, adolescents and the elderly (4). As a systemic form of reticulohistiocytosis, MRH usually has a sudden onset. In $30 \%$ of cases it begins with skin manifestations, in nearly $40 \%$ with joint symptoms and in $29 \%$ of cases with both joint and skin symptoms (5). Skin manifestations have very similar clinical and histological features in all forms of reticulohistiocytosis. Lesions consist of papules and nodules, a few millimeters to $20 \mathrm{~mm}$ in diameter, pink, yellow, brown or gray in color, and are localized on hands, face, arms, trunk, legs, ears and neck $(1,5)$. Although they are usually asymptomatic, one third of patients report pruritus associated with skin lesions (6).

Radiographs of MRH with erosive polyarthritis commonly show well circumscribed periarticular "punched out" lesions and resorption of the juxtaarticularzone, butwithoutperiarticularosteopenia typical in rheumatoid arthritis, or heterotrophic new bone formation typical in the spondylarthritides and gouty arthritis (7). Distal interphalangeal joints are most frequently involved (in 75\% of patients) and are one of defining characteristics of MRH (4). Even though arthritis has a tendency to wax and wane, it progresses into disabling mutilating arthritis in almost $50 \%$ of patients (6).

Besides skin and joint involvement, $\mathrm{MRH}$ can also affect other organs: mucous membranes in almost half of patients (6), lungs in $20 \%$ of cases, less frequently thyroid, salivary glands, heart, kidney, liver 


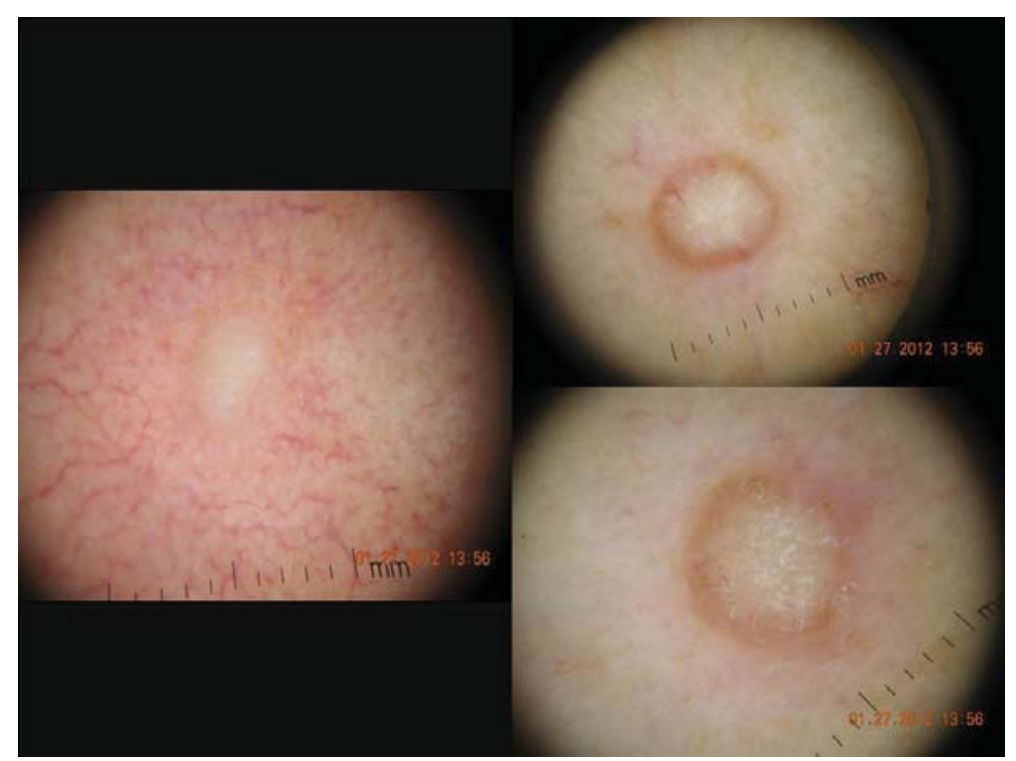

Figure 3. Dermoscopic findigs: forehead lesions showing a homogeneous yellow pattern with central white scar-like streaks (a); right and left upper arm lesions showing the same appearance with an erythematous, and a slightly brownish halo and some vessels at the periphery (b and c)

and gastrointestinal tract (7). In 15\% of cases MRH was reported to be associated with autoimmune diseases: hypothyroidism, Sjögren`s syndrome, diabetes mellitus, primary biliary cirrhosis, systemic sclerosis, idiopathic inflammatory myopathy and systemic lupus erythematosus (7). Associations of $\mathrm{MRH}$ with various malignances have been reported in $25-30 \%$ of cases (8).

There are no specific laboratory tests for diagnosing MRH. Elevated erythrocyte sedimentation rate and anemia are seen in about half of all patients. About one third of patients may have hyperlipidemia. Less commonly, positive rheumatoid factor, antinuclear antibodies, cold agglutinins and cryoglobulinemia are present $(1,4)$. As a noninvasive diagnostic tool, dermoscopy is useful in evaluation of reticulohistiocytomas. Previously described as the "setting sun" pattern, in combination with brown reticular structures and whitish streaks, seen in xanthogranulomas and reticulohistiocytomas, it corresponds with dermoscopy findings in our patient $(2,9)$.

Histopathology findings often show dermal nodular infiltrates composed mainly of histiocytes dissociating collagen fibers. The infiltrates consist of multinucleated giant cells and lipid-laden histiocytes containing an eosinophilic, granular "ground glass" material inside their cytoplasm, also lymphocytes, plasma cells, eosinophils and fibroblasts. Most studies have reported immunoreactivity with CD68 and CD45, suggesting a monocyte-macrophage origin; immunoreactivity with TRAP (tartrate - resistant acid phosphatase) and cathepsin $\mathrm{K}$, suggesting osteoclastic origin of multinucleated cells $(7,8)$. Negative staining with S-100 and CD1a support a non-Langerhans cell histiocytic origin (4), whereas negative staining with CD34 excludes dermatofibrosarcoma protuberans (10). Based only on histopahology, in most cases MRH cannot be differentiated from purely cutaneous forms of reticulohistiocytosis, in which histology shows nodules of epithelioid histiocytes, CD68 positive and generally CD1a and S100 negative $(3,4,5,11)$.

Clinical differentialdiagnosisincludessarcoidosis, xanthoma, xanthogranuloma, fibroxanthoma, lymphoma, lipoid proteinosis, Farber's disease, hystiocytosis $\mathrm{X}$, eruptive histiocytomas. Histology is essential for accurate diagnosis $(4,5)$.

$\mathrm{MRH}$ has a tendency to spontaneously and slowly resolve after $5-8$ years (6), leaving a variable degree of permanent joint and other involved tissue damage, depending on the course of the disease and time of appropriate treatment initiation.

There are no guidelines for the management of $\mathrm{MRH}$ or multiple RHs. Treatment of the primary 

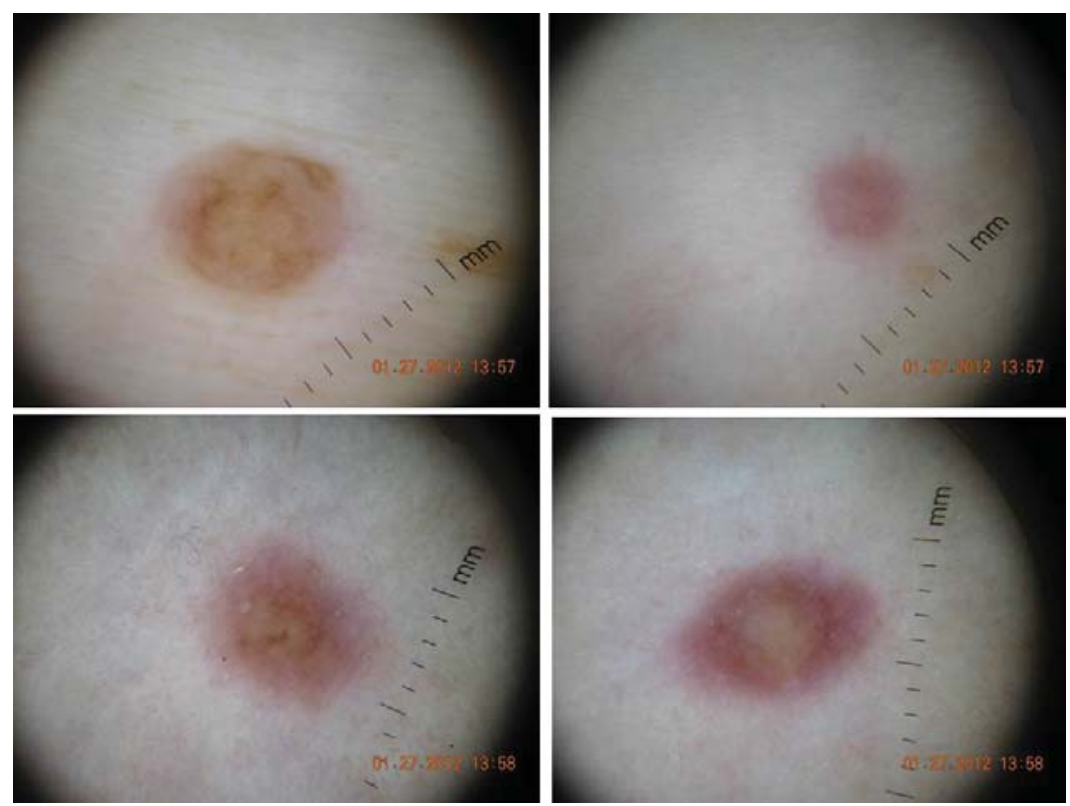

Figure 4. Dermoscopic findings: central homogeneous yellow pattern with whitish scar-like streaks and a bright to dark livid halo with brown linear and reticular structures at the periphery on four different lesions on the lower limbs $(\mathrm{a}-\mathrm{d})$.

malignancy, when associated with $\mathrm{MRH}$, results in complete remission only in few cases. Successful treatment of arthritis has been reported with methotrexate, cyclophosphamide, chlorambucil, alone or in combination with systemic steroids, bisphosphonates (alendronate, zoledronate), TNF- $\alpha$ inhibitors (infliximab, etanercept) $(4,8,12)$. Surgical excision is a therapeutic procedure for individual lesions of solitary or multiple RHs. confined to the skin (1).

Since diffuse cutaneous reticulohistiocytosis without arthropathy as well as isolated reticulohistiocytomas have been described, in some cases of multiple RHs even in the absence of systemic signs and symptoms, MRH should be considered with an appropriate follow-up. In these cases, skin lesions have the same histology as lesions in $(\mathrm{MCH})$, but they are not associated with joint problems or neoplasms. In this case report reticulohistiocytosis was limited to the skin, exhibiting multiple RHs with typical clinical features, characteristic dermoscopy and rather peculiar histopathology presentation, showing features seen in early lesions of $(\mathrm{MCH})$, such as multinuclear cells dissociating collagen fibers with pale eosinophilic and foamy cytoplasm. Apart from surgical excisions, no other treatment options were performed.

\section{Conclusion}

To our knowledge, this is the oldest patient reported to have developed multiple isolated reticulohisiocytomas. The follow up period for these patients has not been precisely established. Our patient was informed about the nature of his condition and he is being followed up at three month intervals.

\section{Abbreviations}

\section{References}

1. Goodman WT, Barrett TL. Hystiocytoses. In: Bolognia JL, Jorizzo JL, Rapini RP, eds. Dermatology. $2^{\text {nd }}$ ed. London: Mosby Elsevier; 2008. p. 1395-410.

2. Kaçar N, Tasli L, Argenziano G, Demirkan N. Reticulohistiocytosis: different dermatoscopic faces and a good response to methotrexate treatment. Clin Exp Dermatol 2010;35(4):e120-2.

3. Chu AC. Histiocytoses. In: Burns T, Breathnach S, Cox N, Griffiths C, editors. Rook's textbook of dermatology. $6^{\text {th }}$ ed. Oxford: Blackwell Publishing Ltd; 2010. p. 55.1-34.

4. Tajirian AL, Malik MK, Robinson-Bostom L, Lally EV. Multicentric reticulohistiocytosis. Clin Dermatol 2006;24:486-92.

5. Luz FB, Gaspar AP, Kalil-Gaspar N, Ramos-e-Silva M. Multicentric reticulohistiocytosis. J Eur Acad Dermatol Venerol 2001;15:524-31. 


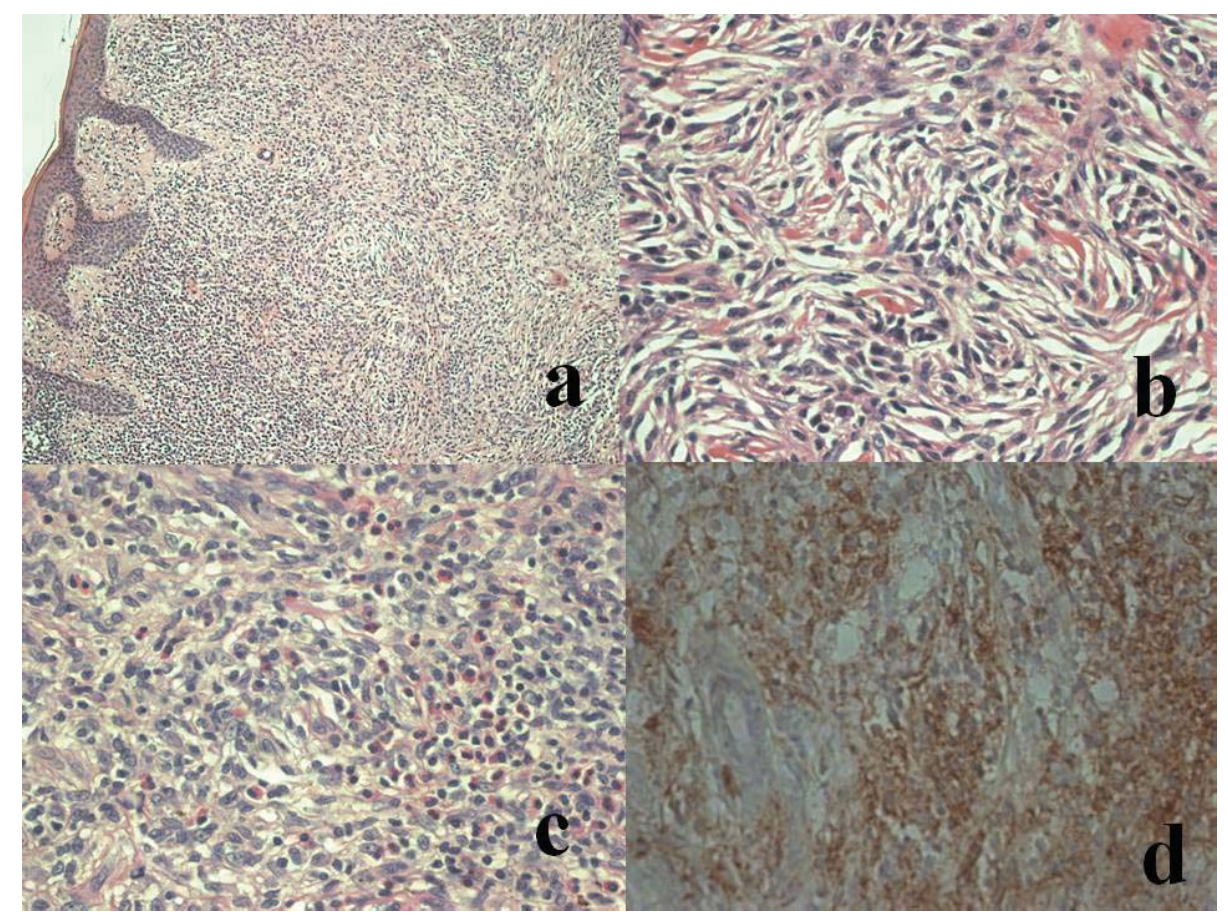

Figure 5. Histopathology of the four excised nodules exhibiting similar characteristics: preserved epidermis over the dermal infiltrate (a) (HEx100); diffuse infiltrates of histiocytes involving the whole dermis showing areas of storiform pattern (b) (HEx400); the infiltrate consisting of some lymphocytes and eosinophylic granulocytes (c) (HEx400); the staining diffusely positive with CD68 (d) (CD68x400)

6. Outland JD, Keiran SJ, Schikler KN, Callen JP. Multicentric reticulohistiocytosis in a 14-year-old girl. Pediatr Dermatol 2002;19(6):527-31.

7. Codriansky KA, Rünger TM, Bhawan J, Kantarci A, Kissin EY. Multicentric reticulohistiocytosis: a systemic osteoclastic disease?. Arthritis \& Rheumatism (Arthritis Care \& Research) 2008;59(3):444-8.

8. Tan BH, Barry CI, Wick MR, White KP, Brown JG, Lee A, et al. Multicentric reticulohistiocytosis and urologic carcinomas: a possible paraneoplastic association. J Cutan Pathol 2011;38:43-8.

9. Hussain SH, Kozic H, Lee JB. The utility of dermatoscopy in the evaluation of xanthogranulomas. Pediatr Dermatol
2008;25:505-6.

10. Kraft S, Granter SR. Fibrous and fibrohistiocytic tumors. In: Barnhill RL, Crowson AN, Magro CM, Piepkorn MW, eds. Dermatopathology. $3^{\text {rd }}$ ed. New York: McGraw-Hill Companies; 2010. p. 766-802.

11. Harvell JD, Barnhill RL. Nodular and diffuse cutaneous infiltrates. In: Barnhill RL, Crowson AN, Magro CM, Piepkorn MW, eds. Dermatopathology. $3^{\text {rd }}$ ed. New York: McGraw-Hill Companies; 2010. p. 98-135.

12. Kalajian AH, Callen JP. Multicentric reticulohistiocytosis successfully treated with infliximab. Arch Dermatol 2008;144(10):1360-6. 


\section{Multipli retikulohistiocitomi kod osobe stare 88 godina - prikaz slučaja}

\section{Sažetak}

Uvod: Retikulohistiocitoze su poremećaji histiocita koje nisu Langerhansovog tipa, nepoznate su etiologije. Javljaju se kao izolovano oboljenje kože u vidu tumora - retikulohistiocitoma (RH), koji mogu biti solitarni ili multipli, neretko difuzno raspoređeni, kada govorimo o difuznoj retikulohistiocitozi kože.

Prikaz slučaja : Prikazujemo pacijenta starosti 88 godina, kod kojeg se javila nagla asimptomatska erupcija čvrstih papula i nodula, smeđih i boje kože, prečnika $6-17$ mm lokalizovanih na čelu, rukama, nogama i glutealnoj regiji. Višestruke ekscizione biopsije sa histopatološkom analizom potvrdile su postavljenu dijagnozu. Nakon jednogodišnjeg praćenja, preostale kožne lezije su ostale iste veličine, a na mestima ekscizije nije bilo znakova recidiva, niti znakova progresije bolesti ili sistemskog zahvatanja.

Diskusija: Multipli RH kao multipli tumori kože uglavnom su manifestacija sistemske bolesti multicentrične retikulohistiocitoze (MRH), koju karakteriše zahvatanje kože i erozivni artritis, najčešće distalnih interfalangealnih zglobova, ali mogu biti zahvaćeni i drugi organi i sluznice, kao što se mogu registrovati i opšte tegobe. Registrovana je udruženost MRH sa hiperlipidemijom, kod oko trećine obolelih, sa različitim malignitetima i sa autoimunim oboljenjima. Klinička diferencijalna dijagnoza multiplih RH obuhvata sarkoidozu, ksantome, ksantogranulome, fibroksantome, limfome, lipoidnu proteinozu, Farberovu bolest, eruptivne histiocitome, histiocitozu X.

Kod RH dermoskopski se opisuje obrazac ,zalazećeg sunca“, u kombinaciji sa smeđim mrežastim strukturama i beličastim žiličastim strukturama, ali se radi o malom broju za sada objavljenih slučajeva.

Histološki, promene na koži u MRH predstavljene su dermalnim nodularnim infiltratima sačinjenim od multinuklearnih džinovskih ćelija i brojnih histiocita sa eozinofilnom sitno zrnastom citoplazmom izgleda „brušenog stakla“. Imunohistohemijski profil infiltrata je: CD68+ i CD45+ što govori o monocitno-makrofagnom poreklu, a S100- i CD1a- govore o histiocitima porekla ne-Langerhansovih ćelija. Negativno bojenje sa CD34 isključuje dermatofibrosarkom protuberans. U najvećem broju slučajeva, diferencijalna dijagnoza MRH u odnosu na izolovane kutane forme retikulohistiocitoza ne može biti zasnovana isključivo na histopatološkim karakteristikama. U izolovanim, solitarnim kutanim RH, nodularni infiltrati sačinjeni su od epteloidnih histiocita. Multipli kutani RH retko se javljaju izolovano, ali se i u takvim slučajevima može očekivati naknadni razvoj sistemske bolesti; tada histološke karakteristike kožnih promena pokazuju osobine karakteristične za $\mathrm{MRH}$, ali nisu udružene sa zglobnim promenama ni malignim neoplazmama.

Solitarni i multipli RH leče se hirurškom ekscizijom, dok su pozitivni rezultati u lečenju artritisa postignuti metotreksatom, ciklofosfamidom i hlorambucilom, samostalno ili u kombinaciji sa sistemskim steroidima, kao i bifosfonatima (alendronat, zoledronat) i inhibitorima TNF- $\alpha$ (infliksimab, etanercept). U nekim slučajevima udruženim sa malignim oboljenjima, lečenjem maligniteta dolazi do kompletne remisije MRH.

Zaključak: U svim slučajevima multiplih retikulohistiocitoma, čak i u odsustvu sistemskih znakova bolesti, neophodno je misliti na multicentričnu retikulohistiocitozu i redovno pratiti pacijenta. Autori prikazuju slučaj do sada najstarijeg pacijenta sa multiplim retikulohistiocitomima sa histološkim osobinama karakterističnim za rane lezije multicentrične retikulohistiocitoze kod koga se u toku dvogodišnjeg praćenja nije razvila sistemska bolest.

\section{Ključne reči}

Non-Langerhans histiocitoza; Dermoskopija; Histologija; Simptomi i znaci; Osobe starije od 80 godina 